\title{
Tobacco use in school students in Afghanistan, Oman and Kuwait and association with parental monitoring: analysis of data from Global School-based Student Health surveys
}

Masood A. Shaikh ${ }^{1}$

Independent Consultant, Karachi, Pakistan. (Correspondence to: Masood Shaikh: Masoodali1@yahoo.com).

\begin{abstract}
Background: Nationally representative data are lacking on cigarette smoking in adolescents in Afghanistan, Oman and Kuwait, which are considered low-income, middle-income and high-income countries respectively of the World Health Organization Eastern Mediterranean Region.

Aims: This study examined the effect of parental monitoring on the tobacco use of adolescent school students in Afghanistan, Oman and Kuwait.

Methods: Using data from the 2014 Afghanistan, 2015 Oman and 2015 Kuwait Global School-based Student Health surveys, factors associated with cigarette smoking and tobacco use among the students in the 30 days before the survey were analysed. These factors included: parental understanding of their problems/worries, parental awareness of how they spent their free time, parents searching their belongings without their approval, and parents checking if homework was done. Logistic regression analysis was used to determine the association between tobacco use and parental monitoring.

Results: The prevalence of cigarette smoking and/or use of other tobacco products by the students on one or more days in the 30 days before the survey was 10.6\% in Afghanistan, 9.3\% in Oman and 28.8\% in Kuwait. Adolescents whose parents understood their problems, were aware of how they spent their free time, and checked if their homework was done were less likely to be current tobacco users in all three countries $(P<0.05)$. Adolescents in Oman and Kuwait whose parents searched their belongings were more likely to use tobacco $(P<0.01)$.
\end{abstract}

Conclusion: The prevalence of tobacco use in the adolescents, especially in Kuwait, suggests the need for better schoolbased health education and promotion programmes in these countries.

Keywords: cigarette smoking, tobacco use, adolescents, parents, Afghanistan, Kuwait, Oman

Citation: Shaikh MA. Tobacco use in school students in Afghanistan, Oman and Kuwait and association with parental monitoring: analysis of data from the Global School-based Student Health Surveys. East Mediterr Health J. 2020;26(1):122-128. https://doi.org/10.26719/2020.26.1.122

Received: 25/02/19; accepted: 01/08/19

Copyright (c) World Health Organization (WHO) 2020. Open Access. Some rights reserved. This work is available under the CC BY-NC-SA 3.0 IGO license (https://creativecommons.org/licenses/by-nc-sa/3.o/igo).

\section{Introduction}

The harmful health effects of tobacco use are widely known and include damage to multiple organ systems and cancer $(1,2)$. It is one of the main causes of the disturbing increase in noncommunicable diseases. Globally, seven million people die each year because of tobacco use (3). The tobacco epidemic is moving from high-income to low- and middle-income countries (4). A recent burden of health study of countries of the Eastern Mediterranean Region (EMR) of the World Health Organization (WHO) identified tobacco use and systolic blood pressure as the leading causes of disability-adjusted life years (DALYs) (5). Strong monitoring of the correlates of the tobacco use epidemic is needed to combat this important public health problem (3).

Among the EMR Member States, Afghanistan is considered a low-income country, Oman a middleincome country and Kuwait a high-income country. Few nationally representative studies on cigarette smoking in adolescents have been carried out in these three
Member States. The Global School-based Student Health Survey (GSHS) is a self-administered questionnaire that assesses various health behaviours and practices in schoolchildren, including the use of tobacco (6). The GSHS was developed by WHO in collaboration with the United States Centers for Disease Control and Prevention (CDC). The survey is conducted in collaboration with the national ministries of health in each country. The data can be used to evaluate the epidemiology and burden of these behaviours and practices and to make statistically sound comparisons between countries on their profile and correlates.

In Afghanistan, the first GSHS was completed in 2014, while in Oman and Kuwait these surveys were first done in 2010 and 2011 respectively. The most recent GSHSs in Oman and Kuwait were done in 2015. This study examines the differences and similarities in adolescent tobacco use and the role of parental monitoring activities on tobacco use in these three countries using recently released GSHS data on nationally representative samples of students. 


\section{Methods}

\section{Sample}

Data from the most recent GSHSs of Afghanistan (2014), Oman (2015) and Kuwait (2015) were used for a secondary analysis. Detailed information on the data collection methods, questionnaire, procedures and data are available at the CDC website (6). Briefly, a two-stage cluster sampling design was used to collect data representing all students in classes 7 to 11 in Afghanistan (typically attended by students aged 13-17 years), and grades 8 to 12 (typically attended by students aged $13-17$ years) in Oman and Kuwait. In stage one, schools were selected with a probability proportional to their enrolment size. In stage two, classrooms within the chosen schools were randomly selected and all students in the selected classes were eligible to participate. In Afghanistan, the school response rate was $97 \%$, student response rate was $87 \%$, overall response rate was $79 \%$ and 2579 students participated in the survey. In Oman, the school response rate was $98 \%$, student response rate was $94 \%$, overall response rate was $92 \%$ and 3468 students participated. In Kuwait, the school response rate was $97 \%$, student response rate was $80 \%$, overall response rate was $78 \%$ and 3637 students participated. All respondents 11 years of age or younger were recoded as 12 years old because there were so few. Respondents 18 years or older were coded as such in the original database.

Participation in the survey was voluntary and all students were informed of the anonymous nature of the questionnaire. Answers were self-reported on a questionnaire with an answer sheet that could be scanned by computer. With the exception of verifying heights and weights, no validation measures were used for the other responses in the survey, including the responses to items used for the present study.

\section{Measurements}

Current tobacco use was the dependent variable and was ascertained by two questions in the GSHS. "During the past 30 days, on how many days did you smoke cigarettes?" and "During the past 30 days, on how many days did you use any tobacco product other than cigarettes, such as ....' In each of the three countries, different types of non-cigarette tobacco products were named. Response options for both questions were the same: 0 days, 1 or 2 days, 3 to 5 days, 6 to 9 days, 10 to 19 days, 20 to 29 days, or all 30 days. For the purpose of these analyses, participants were classified as a current tobacco user if they reported having smoked a cigarette or used any tobacco product for 1 or 2 days or more in the past 30 days.

Four parental monitoring questions were investigated as explanatory variables: "During the past 30 days, how often did your parents or guardians check to see if your homework was done?", "During the past 30 days, how often did your parents or guardians understand your problems and worries?", "During the past 30 days, how often did your parents or guardians really know what you were doing with your free time?", and "During the past 30 days, how often did your parents or guardians go through your things without your approval?". Response options for all four questions were the same and ranged from: never, rarely, sometimes, most of the time, or always. Responses of "most of the time" and "always" were combined for each question and coded as "yes" (i.e. having parental monitoring) and all other responses were coded as "not having parental monitoring". Additional questions asked were on: age when the respondents first tried smoking a cigarette, attempts to stop smoking in the past 12 months, number of days other people smoked in the respondents' presence in the seven days before the survey and parental tobacco use.

\section{Statistical analysis}

Use of tobacco products, cigarette smoking and other variables related to cigarette smoking (age at first smoking a cigarette, attempts to quit cigarette smoking and number of days a week other people smoked cigarettes in your presence) were examined and recorded as number of students and weighted percentages. Differences in current tobacco use in relation to the following variables were evaluated using Rao-Scott chi-squared test: age, sex, parents/guardians use of tobacco, and parental monitoring (understand your problems and worries; aware of your free-time activities, go through your things without permission and check your homework is done). This test is a design-adjusted version of the Pearson chi-squared test for categorical variables, and the design-adjusted version of $t$-test for the continuous variable age

For each country, four logistic regression analyses were done to evaluate the association between each individual parental monitoring variable and current tobacco use for each country. Alogistic regression analyses including all four parental monitoring variables was then done for each country to predict the current tobacco use status. Measures are reported as unadjusted odds ratios (ORs), adjusted odds ratios (aORs) and associated 95\% confidence intervals (CIs). All analyses were carried out using Stata 15.

\section{Results}

Within the recall period of the 30 days before the survey, $10.6 \%$ of students in Afghanistan, $28.8 \%$ in Kuwait and $9.3 \%$ in Oman reported having smoked cigarettes and/or used other tobacco products on one or more days.

Table 1 shows the prevalence of cigarette smoking, tobacco use, and related factors in adolescents attending school in Afghanistan, Oman and Kuwait. In Afghanistan, the percentage of the school students who were current cigarettes smokers was $7.9 \%$, and the percentage who were current tobacco users was $7.5 \%$. In Oman the percentages were $6.8 \%$ and $6.3 \%$ respectively for current cigarette smokers and tobacco users. In Kuwait, the percentages were $22.0 \%$ for current cigarette smokers and $22.2 \%$ for current tobacco users. Almost half the students in Afghanistan (47.4\%) reported that other people had smoked in their presence in the seven days before the survey, while the percentages were $26.1 \%$ in Oman and 


\begin{tabular}{|c|c|c|c|}
\hline \multirow[t]{2}{*}{ Variable } & $\begin{array}{l}\text { Afghanistan } \\
(n=2579)\end{array}$ & $\begin{array}{c}\text { Oman } \\
(n=3468)\end{array}$ & $\begin{array}{l}\text { Kuwait } \\
(n=3637)\end{array}$ \\
\hline & No. (\%) & No. (\%) & No. (\%) \\
\hline \multicolumn{4}{|l|}{ Current cigarette smoker } \\
\hline Yes & $167(7.9)$ & $225(6.8)$ & $715(22.0)$ \\
\hline No & $2349(92.1)$ & $3180(93.2)$ & $2693(78.0)$ \\
\hline Missing data & 63 & 63 & 229 \\
\hline \multicolumn{4}{|c|}{ Age at which first tried to smoke a cigarette (years) } \\
\hline Never smoked & $2034(83.7)$ & $2927(87.4)$ & $2193(65.4)$ \\
\hline$\leq 7$ & $124(5.4)$ & $98(3.0)$ & $225(7.1)$ \\
\hline 8 or 9 & $81(3.8)$ & $50(1.6)$ & $185(6.2)$ \\
\hline 10 or 11 & $70(3.1)$ & $84(2.6)$ & $166(5.2)$ \\
\hline 12 or 13 & $35(1.4)$ & $66(2.0)$ & $236(7.2)$ \\
\hline 14 or 15 & $42(1.7)$ & $73(2.2)$ & $211(6.5)$ \\
\hline 16 or 17 & $14(0.6)$ & $32(0.9)$ & $75(2.2)$ \\
\hline$\geq 18$ & $10(0.3)$ & $10(0.3)$ & $5(0.2)$ \\
\hline Missing data & 169 & 128 & 341 \\
\hline \multicolumn{4}{|l|}{ Tried to quit cigarette smoking } \\
\hline Never smoked & $2261(91.8)$ & $3135(92.8)$ & $2414(73.1)$ \\
\hline Have not smoked in the past 12 months & $62(2.9)$ & $71(2.1)$ & $246(7.6)$ \\
\hline Yes & $82(4.0)$ & $102(3.2)$ & $412(13.2)$ \\
\hline No & $33(1.3)$ & $65(1.9)$ & $190(6.1)$ \\
\hline Missing data & 141 & 95 & 375 \\
\hline \multicolumn{4}{|c|}{ No. of days a week other people smoked cigarettes in your presence } \\
\hline 0 & $1405(52.6)$ & $2551(73.9)$ & $1234(35.5)$ \\
\hline 1 or 2 & $675(28.0)$ & $469(13.8)$ & $847(24.7)$ \\
\hline 3 or 4 & $209(9.2)$ & $155(4.6)$ & $451(13.6)$ \\
\hline 5 or 6 & $100(4.1)$ & $84(2.5)$ & $186(5.5)$ \\
\hline 7 & $145(6.1)$ & $176(5.2)$ & $696(20.7)$ \\
\hline Missing data & 45 & 33 & 223 \\
\hline \multicolumn{4}{|l|}{ Current tobacco user } \\
\hline Yes & $184(7.5)$ & $210(6.3)$ & $735(22.2)$ \\
\hline No & $2360(92.5)$ & $3217(93.7)$ & $2710(77.8)$ \\
\hline Missing data & 35 & 41 & 192 \\
\hline
\end{tabular}

All frequencies are unweighted, while percentages are weighted.

\section{$64.5 \%$ in Kuwait.}

Table 2 shows the associations between current tobacco use of the school students (smoked cigarettes and/ or used tobacco) and sociodemographic characteristics and parental monitoring. Significantly more current tobacco users were male: $74.9 \%$ in Afghanistan, $81.7 \%$ in Oman and $65.1 \%$ in Kuwait $(P<0.01)$. Age and current tobacco use were also significantly associated in Oman and Kuwait, with older students more likely to report tobacco use in any form $(P<0.01)$.

In all three countries, current tobacco use was significantly associated with the parental monitoring: monitoring if homework was done, parental understanding of problems and worries, and monitoring free-time activities $(P<0.01)$. Fewer school students who were current tobacco users were monitored by their parents in these ways. In Oman and Kuwait, significantly more students whose parents went over their things without their approval smoked $(P<0.01)$, but this association was not significant in Afghanistan.

Table 3 shows the results of the logistic regression analyses of the association between current tobacco use and parental monitoring activities in the school students in the three countries. In the univariate logistic regression analyses, parental understanding, monitoring of free-time activities and checking homework were statistically significant associated with lower likelihoods of smoking in the students. However, parents going 


\begin{tabular}{|c|c|c|c|c|c|c|}
\hline \multirow[t]{4}{*}{ Variable } & \multirow{2}{*}{\multicolumn{2}{|c|}{ Afghanistan $\left(n=2563^{a}\right)$}} & \multirow{2}{*}{\multicolumn{2}{|c|}{$\begin{array}{l}\text { Oman }\left(n=3453^{a}\right) \\
\text { Current tobacco user }\end{array}$}} & \multicolumn{2}{|c|}{ Kuwait $\left(n=3485^{a}\right)$} \\
\hline & & & & & & \\
\hline & Yes & No & Yes & No & Yes & No \\
\hline & No. (\%) & No. (\%) & No. (\%) & No. (\%) & No. (\%) & No. (\%) \\
\hline \multicolumn{7}{|l|}{ Age (years) } \\
\hline 12 years or less & $21(0.8)$ & $97(3.2)$ & $11(0.3)$ & $67(2.0)$ & $31(0.9)$ & $50(1.3)$ \\
\hline 13 & $22(0.7)$ & $327(10.8)$ & $14(0.5)$ & $342(9.8)$ & $85(2.3)$ & $482(12.6)$ \\
\hline 14 & $43(1.7)$ & $490(18.6)$ & $27(0.9)$ & $50416.3)$ & $131(3.8)$ & $569(15.1)$ \\
\hline 15 & $45(2.1)$ & $466(18.0)$ & $70(2.1)$ & $669(18.8)$ & $170(5.6)$ & $472(15.2)$ \\
\hline 16 & $48(2.1)$ & $418(17.0)$ & $66(1.8)$ & $690(18.5)$ & $196(6.1)$ & $429(12.6)$ \\
\hline 17 & $27(1.4)$ & $240(11.0)$ & $79(2.4)$ & $648(19.0)$ & $240(7.1)$ & $383(10.9)$ \\
\hline 18 years or more & $35(1.7)$ & $247(10.9)$ & $45(1.4)$ & $209(6.3)$ & $99(3.0)$ & $116(3.5)$ \\
\hline Missing values & 7 & 30 & 2 & 10 & 11 & 21 \\
\hline Mean (SD) & $15.4(1.7)$ & $15.2(1.7)$ & $15.9(1.5)$ & $15.4(1.5)$ & $15.6(1.5)$ & $15.0(1.5)$ \\
\hline$P$-value ${ }^{\mathrm{b}}$ & \multicolumn{2}{|c|}{0.496} & \multicolumn{2}{|c|}{0.006} & \multicolumn{2}{|c|}{0.001} \\
\hline \multicolumn{7}{|l|}{ Sex } \\
\hline Male & $135(74.9)$ & $908(53.2)$ & $236(81.7)$ & $1377(46.6)$ & $586(65.1)$ & $1024(43.7)$ \\
\hline Female & $86(25.1)$ & $1350(46.8)$ & $58(18.3)$ & $1718(53.4)$ & $339(34.9)$ & $1467(56.3)$ \\
\hline Missing values & 27 & 57 & 20 & 44 & 38 & 31 \\
\hline$P$-value & \multicolumn{2}{|c|}{0.003} & \multicolumn{2}{|c|}{$<0.0001$} & \multicolumn{2}{|c|}{0.008} \\
\hline \multicolumn{7}{|c|}{ Parents/guardians use tobacco } \\
\hline Neither & $134(58.4)$ & $1905(81.8)$ & $160(53.8)$ & $2747(88.0)$ & $366(40.6)$ & $1685(68.0)$ \\
\hline Father/male guardian & $56(25.4)$ & $320(15.2)$ & $55(18.2)$ & $223(7.3)$ & $305(34.1)$ & $659(26.5)$ \\
\hline Mother/female guardian & $16(7.0)$ & $24(1.3)$ & $238.0)$ & $7(0.3)$ & $80(8.9)$ & $23(0.9)$ \\
\hline Both & $15(5.4)$ & $13(0.5)$ & $19(6.8)$ & $15(0.5)$ & $88(9.6)$ & $39(1.6)$ \\
\hline Don't know & $11(3.8)$ & $29(1.2)$ & $38(13.2)$ & $1243.9)$ & $60(6.8)$ & $77(3.0)$ \\
\hline Missing values & 16 & 24 & 19 & 23 & 64 & 39 \\
\hline \multicolumn{7}{|c|}{ Parental monitoring (understand your problems and worries) } \\
\hline Yes & $48(20.2)$ & $1159(54.1)$ & $87(10.3)$ & $1263(6.6)$ & $221(23.8)$ & $877(36.0)$ \\
\hline No & $174(79.8)$ & $977(45.9)$ & $203(89.7)$ & $1787(93.4)$ & $686(76.2)$ & $1564(64.0)$ \\
\hline Missing values & 26 & 179 & 24 & 89 & 56 & 81 \\
\hline$P$-value & & & & & & \\
\hline \multicolumn{7}{|c|}{ Parental monitoring (aware of your free-time activities) } \\
\hline Yes & $60(27.6)$ & $1189(54.8)$ & $72(24.2)$ & $1360(43.9)$ & $238(26.7)$ & $1143(47.1)$ \\
\hline No & $156(72.4)$ & $940(45.2)$ & $227(75.8)$ & $1728(56.1)$ & $651(73.3)$ & $1286(52.9)$ \\
\hline Missing values & 32 & 186 & 15 & 51 & 74 & 93 \\
\hline$P$-value & & & & & & \\
\hline \multicolumn{7}{|c|}{ Parental monitoring (go through your things without permission) } \\
\hline Yes & $38(20.2)$ & $432(19.9)$ & $54(19.2)$ & $185(6.0)$ & $167(19.1)$ & $333(13.9)$ \\
\hline No & $190(79.8)$ & $1768(80.1)$ & $241(80.8)$ & $2914(94.0)$ & $712(80.9)$ & $2078(86.1)$ \\
\hline Missing values & 20 & 115 & 19 & 400 & 84 & 111 \\
\hline$P$-value & \multicolumn{2}{|c|}{0.9476} & \multicolumn{2}{|c|}{$<0.0001$} & \multicolumn{2}{|c|}{0.008} \\
\hline \multicolumn{7}{|c|}{ Parental monitoring (check your homework is done) } \\
\hline Yes & $55(24.1)$ & $1003(44.8)$ & $103(35.4)$ & $1552(50.7)$ & $255(28.3)$ & $882(37.3)$ \\
\hline No & $178(75.9)$ & $1178(55.2)$ & $189(64.6)$ & $1515(49.3)$ & $640(71.7)$ & $1544(62.7)$ \\
\hline Missing values & 15 & 134 & 22 & 72 & 68 & 96 \\
\hline$P$-value & \multicolumn{2}{|c|}{0.001} & \multicolumn{2}{|c|}{0.0001} & & \\
\hline
\end{tabular}

SD: standard deviation.

${ }^{a}$ For 16 records in Afghanistan, 15 records in Oman, and 152 records in Kuwait, information on current tobacco use (defined as current cigarette smoker and/or current tobacco user) were missing. ${ }^{b}$ For differences between the mean ages of smokers and non-smokers. 


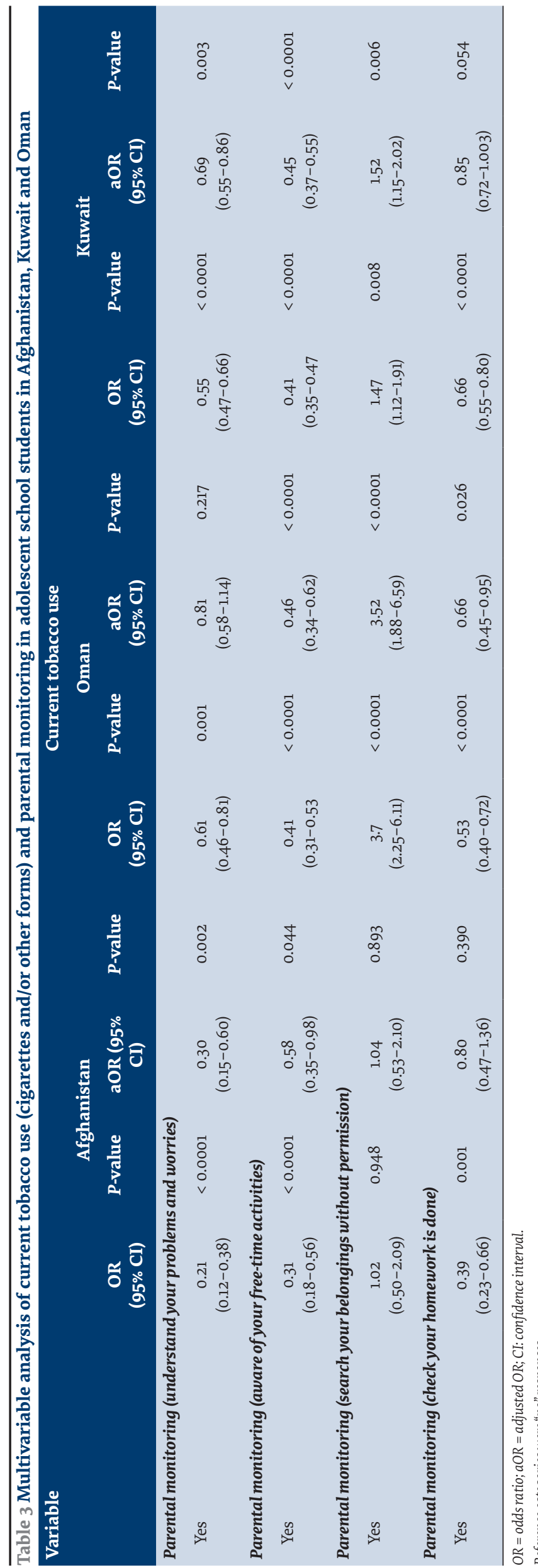

over respondents' things without their approval was significantly associated with a greater likelihood of students smoking in Oman (OR $=3.70$; 95\% CI: 2.25 6.11) and Kuwait (OR = 1.47; 95\% CI: 1.12-1.91).

When adjusting for all covariates in the multivariable logistic regression analysis, parental monitoring was also associated with a lower likelihood of tobacco use, except for parents going over things without respondent's approval, which was associated with higher aORs of tobacco use. However, the associations were not statistically significant for some variables, as shown in Table 3. In Oman, school students whose parents went over their things without their approval were significantly more likely to use tobacco $(\mathrm{aOR}=3.52 ; 95 \% \mathrm{CI}: 1.88-6.59)$, and also in Kuwait $(\mathrm{aOR}=1.52 ; 95 \%$ CI: $1.15-2.02)$. The Hosmer-Lemeshow goodness-of-fit test showed that multivariable logistic regression models with parental monitoring covariates were good models for tobacco use in all three countries.

\section{Discussion}

In this study, the most recent data from the nationally representative GSHSs were used to determine the prevalence of cigarette smoking and tobacco use in other forms in school students in Afghanistan, Oman and Kuwait and their association with parental monitoring activities.

In the 30 days before the survey, the lowest tobacco use was reported in Oman, followed by Afghanistan and then Kuwait. In Afghanistan 7.9\% of the school students had smoked cigarettes on one or more days in the 30 days before the survey and $7.5 \%$ had used other tobacco products; overall $10.6 \%$ of the students had used tobacco in either cigarette or other forms. In Oman, $6.8 \%$ of the students had smoked cigarettes on one or more days and $6.3 \%$ had used other tobacco products; overall $9.3 \%$ had used tobacco in either cigarettes or other forms. In Kuwait, $22.0 \%$ had smoked cigarettes on one or more days and $22.2 \%$ had used other tobacco products; overall $28.8 \%$ had used tobacco in either cigarettes or other forms.

These figures clearly show a substantial overlap in the use of cigarettes and other tobacco products by students. These figures highlight the need for schoolbased programmes offering support to those who want to quit smoking cigarettes and the use of other tobacco products. Tobacco use in school students in Kuwait was higher than in Afghanistan and Oman combined. Taxation has been used to reduce the tobacco use epidemic, but results are inconclusive (7). A recent study in Bangladesh concluded that high tax share alone may not be a good measure of effective tobacco taxation in low-income countries, especially in countries with a complex tax arrangement, relatively cheap tobacco products and a growing affordability of tobacco products, which emphasizes the need for better and targeted health promotion activities (8). Although cigarette smoking has decreased in people 
under 18 years in the United States of America, the rate did not change from 2017 to 2018. In addition, e-cigarette use has increased significantly in these young people in the same period (9).

The GSHS asks four questions about parental monitoring of adolescents' activities in the 30 days before the survey. With the exception of parents going through adolescent's things without their permission most of the time or always, the other three monitoring activities appear to inhibit adolescents from using tobacco in any form in the three countries. It could be hypothesized that this type of control of adolescents (going through their belongings without permission) could result in rebellion in the form tobacco use. However, the cross-sectional nature of the survey does not allow cause-effect relationships to be determined. However, the association between the other three types of parental monitoring and lower tobacco use is positive and such monitoring needs to be further encouraged.

\section{Conclusion}

The proportion of adolescent school students smoking cigarettes and using tobacco in other forms in Afghanistan, Oman and especially Kuwait is disturbing and suggests the need for better school-based health education and promotion programmes in these countries. In addition, services to help support students who want to stop using tobacco need to be provided in a trusting and secure environment within schools. The association of parental monitoring and use of tobacco is interesting and further studies are needed to elucidate a casual role, if any.

Funding: None.

Competing interests: None declared.

\section{Consommation du tabac par les élèves d'Afghanistan, d'Oman et du Koweït et lien avec la surveillance parentale : analyse des données de l'enquête mondiale sur la santé des élèves en milieu scolaire}

\section{Résumé}

Contexte : Les données représentatives au plan national sur le tabagisme par cigarettes chez les adolescents d'Afghanistan, d'Oman et du Koweït font défaut; ces trois pays sont considérés respectivement comme des pays à revenu faible, intermédiaire et élevé de la Région de l'Organisation mondiale de la Santé pour la Méditerranée orientale.

Objectifs : La présente étude a examiné l'effet de la surveillance parentale sur le tabagisme des élèves adolescents d'Afghanistan, d'Oman et du Koweït.

Méthodologie : Sur la base des données des enquêtes mondiales sur la santé des élèves en milieu scolaire menées en 2014 en Afghanistan, en 2015 à Oman et au Koweït, les facteurs associés au tabagisme par cigarettes et à la consommation de tabac chez les adolescents dans les 30 jours ayant précédé les enquêtes ont fait l'objet d'une analyse. Ces facteurs incluaient : la compréhension par les parents de leurs problèmes et soucis, la connaissance par les parents de l'occupation qu'ils font de leur temps libre, le fait que leurs parents fouillent ou non dans leurs affaires sans leur consentement, et le contrôle par les parents de l'exécution des devoirs à faire à la maison. L'analyse de régression logistique a été utilisée pour déterminer le lien entre la consommation du tabac et la surveillance parentale.

Résultats : La consommation de cigarettes et/ou d'autres produits du tabac par les élèves adolescents pendant un ou plusieurs jours au cours des 30 jours ayant précédé l'enquête était de 10,6\% en Afghanistan, de 9,3\% à Oman et de 28,8\% au Koweï. Les adolescents dont les parents comprenaient les problèmes, connaissaient l'occupation qu'ils faisaient de leur temps libre et vérifiaient l'exécution des devoirs à faire à la maison étaient beaucoup moins susceptibles de consommer du tabac à ce moment-là dans les trois pays $(p<0,05)$. Les adolescents d'Oman du Koweït dont les parents fouillaient les affaires sans leur consentement étaient beaucoup plus susceptibles de consommer $\operatorname{du} \operatorname{tabac}(p<0,01)$.

Conclusions : La prévalence du tabagisme chez les adolescents, surtout au Koweït, met en évidence la nécessité d'améliorer l'éducation sanitaire et les programmes de promotion de la santé en milieu scolaire dans ces pays.

$$
\begin{aligned}
& \text { تعاطي التبغ بين طلاب المدارس في أفغانستان وعُمان والكويت، وارتباط ذلك بالرقابة الأبوية: تحليل البيانات من المست العالمي لصحة }
\end{aligned}
$$

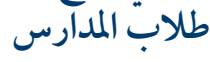

$$
\begin{aligned}
& \text { مسعود علي شيخ } \\
& \text { الخلاصة } \\
& \text { الخلفية: لا توجد بيانات مُعبِّة عن الأوضاع الوطنية حول تدخين السجائر بين المراهقين في أفغانستان، وعُمان، و الكويت. } \\
& \text { الأهداف: تناولت الدراسة أثر الرقابة الأبوية على معدل تعاطي التبغ بين طلاب المدارس المراهقين في أفغانستان، وعُان، والكويت. }
\end{aligned}
$$

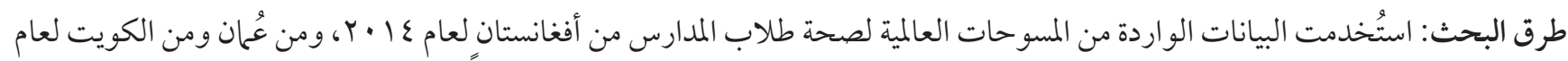

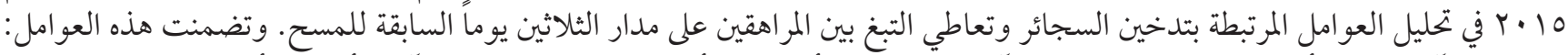

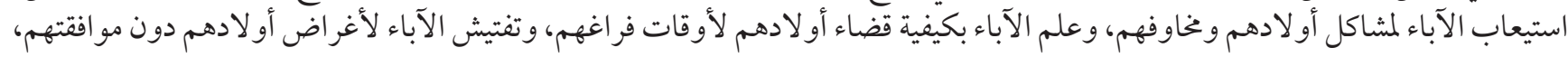


وتحقُق الآباء من أداء أولادهم لفروضهم المدرسية. وأجري تحليل الانحدار اللوجستي لتقييم الارتباط بين معدلات تعاطي التبغ والرقابة الأبوية.

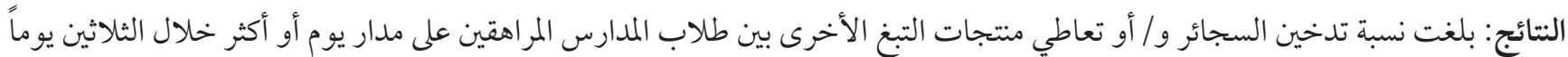

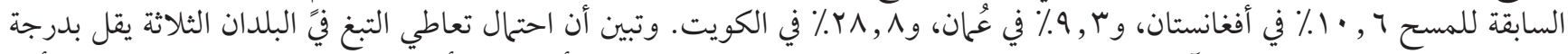

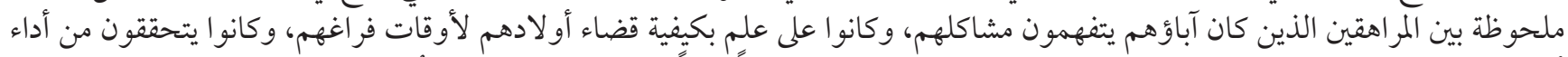

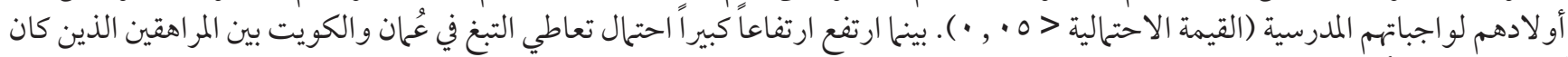

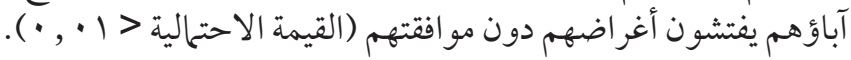

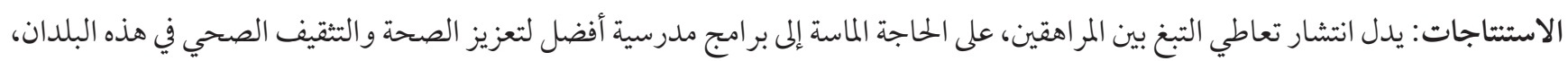
خاصة في الكويت.

\section{References}

1. Mehrotra R, Yadav A, Sinha DN, Parascandola M, John RM, Ayo-Yusuf O, et al. Smokeless tobacco control in 180 countries across the globe: call to action for full implementation of WHO FCTC measures. Lancet Oncol. 2019;20(4):e208-e217. https://doi. org/10.1016/S1470-2045(19)30084-1

2. Fisher MT, Tan-Torres SM, Gaworski CL, Black RA, Sarkar MA. Smokeless tobacco mortality risks: an analysis of two contemporary nationally representative longitudinal mortality studies. Harm Reduct J. 2019;16(1):27. https://doi.org/10.1186/s12954-0190294-6

3. WHO report on the global tobacco epidemic, 2017: monitoring tobacco use and prevention policies. Geneva: World Health Organization; 2017. (https://apps.who.int/iris/bitstream/handle/10665/255874/9789241512824-eng.pdf?sequence=1, accessed 28 April 2019).

4. Myths and facts. World Bank; 2011 http://documents.worldbank.org/curated/en/410971468161663836/pdf/884910BRIoMythoBox385225BoooPUBLICo.pdf, accessed 28 April, 2019).

5. GBD 2015 Eastern Mediterranean Region Collaborators. Danger ahead: the burden of diseases, injuries, and risk factors in the Eastern Mediterranean Region, 1990-2015. Int J Public Health. 2018;63(Suppl 1):11-23. https://doi.org/10.1007/s00038-017-1017-y

6. Global School-based Student Health Survey (GSHS). Centers for Diseases Control and Prevention; 17 May 2016 (https://www.cdc. gov/gshs/background/index.htm, accessed 28 April 2019).

7. Guindon GE, Paraje GR, Chaloupka FJ. The impact of prices and taxes on the use of tobacco products in Latin America and the Caribbean. Am J Public Health. 2015;105(3):e9-19. https://doi.org/10.2105/AJPH.2014.302396.

8. Nargis N, Hussain AG, Goodchild M, Quah AC, Fong GT. A decade of cigarette taxation in Bangladesh: lessons learnt for tobacco control. Bull World Health Organ. 2019;97(3):221-9. https://doi.org/10.2471/BLT.18.216135

9. Printz C. Experts see successes, trouble spots in data on tobacco usage: as cigarette smoking rates among adults decline, a public health crisis among young people emerges. Cancer. 2019;125(10):1581-2. https://doi.org/10.1002/cncr.32153 